\title{
Tecnura
}

\section{A Comprehensive Review of Sustainability in Isolated Colombian Microgrids}

\section{Una revisión integral de la sostenibilidad en las microrredes aisladas colombianas}

\author{
Alejandra Rodríguez-Zabala (iD)1, Dahiana López-García (iD)2, Sandra Ximena Carvajal-Quintero (iD)3 \\ Adriana Arango-Manrique ${ }^{\text {iD }} 4$
}

Fecha de Recepción: 02 de agosto de 2021

Fecha de Aceptación: 12 de agosto de 2021

Cómo citar: Rodríguez-Zabala., A. López-García., D. Carvajal-Quintero., S.X. y Arango-Manrique., A. (2021). A Comprehensive Review of Sustainability in Isolated Colombian Microgrids. Tecnura, 25(70), 126-145. https:/ / doi.org/10.14483/22487638.18619

\begin{abstract}
Context: The increase in rural electrification projects has led to the emergence of technologies that allow operating local distribution networks such as isolated microgrids. However, the successful implementation of these isolated microgrids requires that their planning, operation, monitoring, and control consider a framework that allows maintaining technical, economic, and environmental sustainability over an extended time horizon. Therefore, this paper proposes a model that allows identifying the main technical, economic, regulatory, and environmental variables that should be considered for the successful planning of Colombian rural electrification solutions.

Methodology: This paper proposes the use of System Dynamics to create a model that allows describing the causal relationships between the different variables essential for the design and operation of isolated microgrids. To this effect, the identification of the related variables and their corresponding classification are presented, together with a model of theoretical expectations about their relationships.

Results: A model that integrates and describes the behavior of the main variables involved in the operation of microgrids was formulated to analyze the possible implementation of policies that guarantee the sustainability of these solutions and enhance the use of renewable energy resources while improving the continuity of the electric energy supply.

Conclusions: It was possible to show that operation by means of isolated microgrids with the integration of Distributed Energy Resources is a sustainable solution for rural electrification in Colombia, given that it enhances the use of generation resources with a reduced carbon footprint that are present in the territories under study. These microgrids have the potential to improve the living conditions of users by reducing unsatisfied basic needs.

\footnotetext{
${ }^{1}$ Electrical engineer. Manizales, Colombia. Email: alerodriguezzab@unal.edu.co

${ }^{2}$ Electrical engineer, Master's degree in Electrical Engineering. Professor at Universidad Nacional de Colombia, Sede Manizales. Manizales, Colombia. Email: dahlopezgar@unal.edu.co

${ }^{3}$ Electrical engineer, Specialist in Electrical Engineering, Master's degree in Electrical Engineering, PhD in Electrical Engineering. Professor at Universidad Nacional de Colombia, Sede Manizales. Manizales, Colombia. Email: sxcarvajalq@unal.edu.co

${ }^{4}$ Electrical engineer, Master's degree in Industrial Automatization, PhD in Engineering. Professor at Universidad del Norte. Barranquilla, Colombia. Email: adrianaarango@uninorte.edu.co
} 
A Comprehensive Review of Sustainability in Isolated Colombian Microgrids

Rodríguez-Zabala., A. López-García., D. Carvajal-Quintero., S.X. y Arango-Manrique., A

Funding: Universidad Nacional de Colombia - Sede Manizales.

Keywords: system dynamics, rural electrification, causal model, isolated microgrid operation, distributed energy resources

\section{Resumen}

Contexto: El aumento de los proyectos de electrificación rural ha propiciado la aparición de tecnologías que permiten operar redes de distribución local como microrredes aisladas. Sin embargo, la implementación exitosa de estas microrredes requiere que su planificación, operación, monitoreo y control considere un marco que permita mantener la sostenibilidad integral en un horizonte de tiempo extendido. Por ello, este trabajo propone un modelo que permite identificar las principales variables técnicas, económicas, regulatorias y ambientales que deben ser consideradas para la planificación exitosa de soluciones de electrificación rural en Colombia.

Metodología: Este artículo propone el uso de la Dinámica de Sistemas para la creación de un modelo que permita describir las relaciones causales entre las diferentes variables que deben ser consideradas en el diseño y operación de microrredes aisladas. Para ello se presentan la identificación de las variables relacionadas, su respectiva clasificación y un modelo de expectativas teóricas sobre la relación de estas variables entre sí.

Resultados: Se formuló un modelo que integra y describe el comportamiento de las principales variables involucradas en la operación de las microrredes para analizar la posible implementación de políticas que garanticen la sostenibilidad de estas soluciones y potencien el uso de recursos energéticos renovables, a la par que mejoren la continuidad del suministro de energía eléctrica.

Conclusiones: Fue posible mostrar que la operación por microrredes aisladas con integración de Recursos Energéticos Distribuidos es una solución sostenible para la electrificación rural en Colombia, pues potencia el uso de los recursos de generación con huella de carbono reducida presentes en los territorios estudiados. Estas microrredes tienen el potencial de mejorar las condiciones de vida de los usuarios al disminuir las necesidades básicas insatisfechas.

Financiamiento: Universidad Nacional de Colombia.

Palabras clave: dinámica de sistemas, electrificación rural, modelo causal, operación de microrredes aisladas, recursos energéticos distribuidos

\section{Table of Contents}

Introduction

\section{Energy challenges of the Colombian Non-Interconnected}

Zones (ZNI)

Sustainability challenges in the Colombian ZNI . . . . . . . . . . . . . . . . . . 131

International experiences 
Proposed solution for the energization of the Colombian non-interdonnected zones

Technical cycle . . . . . . . . . . . . . . . . . . . . . 137

Environmental cycle . . . . . . . . . . . . . . . . . . . . . . 139

Economic cycle . . . . . . . . . . . . . . . . . . . . . . 139

Conclusions

\section{INTRODUCTION}

Microgrids comprise the medium and low-voltage portion of an electrical distribution system that can operate in island mode, interconnected with other microgrids or directly connected to the main network (Bordons et al., 2015, Gaona et al., 2015). Microgrids adopt a variety of Distributed Energy Resources (DERs) such as non-conventional renewable energy sources (FNCER, by its Spanish initials), energy storage systems (BES), and active demand participation, which are coordinated through communication and control systems (López-García et al., 2018). This kind of operation allows improving the reliability and electrical safety of the different distribution networks, and, at the same time, it can provide greater flexibility of operation over the medium and long term (Chowdhury et al., 2009). The technical characteristics of microgrids make them a relevant alternative for the electrification of isolated and remote areas, which are the result of the topography and environmental conditions of each region (Chowdhury et al., 2009).

The transition to a new energy model such as microgrids is subject to different political and technological barriers, due to the variety of generation sources, the characteristics of the region, the control and storage of the primary resource (given its intermittency, which is associated with climatological conditions), and changes in the operation of the distribution system (Bordons et al., 2015).

This paper reviews the energy challenges in the Colombian Non-Interconnected Zone (ZNI), together with the sustainability challenges that arise during the implementation of isolated microgrids, international experiences related to these solutions, and the proposal of a solution hypothesis to the problems related to the provision of the ZNI's electric power service through isolated microgrids by using the System Dynamics (SD) methodology.

The paper is organized as follows: section 1 introduces the challenges for the provision of electric power service in the Colombian ZNI; section 2 presents some international experiences regarding the installation of isolated microgrids; section 3 provides the diagnosis of ZNI, which determines whether the use of microgrids is possible in Colombia; section 4 proposes a solution hypothesis by 
designing a causal diagram implemented in SD; and finally, some concluding remarks are presented about the possibility of the ZNI being the natural laboratory for isolated microgrids in Colombia.

\section{Methodology}

System thinking is the methodology used in this research. This methodology was used for the first time in the 1950s to analyze complex behaviors in different contexts (Ahmad et al., 2016), and it has been implemented for more than 40 years in the field of energy due to its non-linearity, feedback, delays, and dynamic interaction between the different factors that make up a system (Gómez et al., 2017).

This methodology is appropriate for dynamic-behavioral problems that can be analyzed in a time horizon where delays can be included (Gómez et al., 2017). System Dynamics (SD) is a systematic thinking tool; it is a method that allows the recognition of bidirectional properties, organizes parts into systems, and takes new perspectives for decision-making (Liévano Martínez \& Londoño, 2012).

The development of the methodology is divided in four stages, which are listed below (LópezGarcía, 2018):

1. Problem structure: In this stage, the research problem is defined, as well as the limits and the scope. Here, a state-of-the-art review is developed for identifying the problem to be addressed.

2. Causal-relationship model: The main objective of this stage is the creation of a conceptual diagram based on the theoretical expectations of the system's behavior, where the relationships between the independent and dependent variables of interest are analyzed.

3. Dynamic model: In this stage, SD is used, which is a tool that allows for scenario analysis considering the characteristics of the problem. The result is a systems diagram that shows all the problem-related variables. The evolution of variables is analyzed over a defined time horizon depending on their relationship with the different components of the system. The stability of the model is evaluated, and sensitivity tests are carried out on the main parameters to refine the system's behavior.

4. Scenario design and model: In this stage, different solution scenarios are tested and evaluated for the problem identified in the first stage. Therefore, the parameters or variables that can generate a potentially significant impact are identified. Then, the coherence of the model is evaluated with extreme, optimistic, and pessimistic scenarios. Finally, the performance and behavior of the variables are evaluated in each proposed scenario.

The formulation and validation of the formal model are proposed for future works, together with different solution scenarios for the identified problem. 


\section{ENERGY CHALLENGES OF THE COLOMBIAN NON-INTERCONNECTED}

\section{ZONES (ZNI)}

The Colombian Non-Interconnected Zone (ZNI, by its Spanish initials) is defined as a "geographic area where the public electricity service is not provided through the National Interconnected System" (Law 143 of 1994), and it represents $51 \%$ of the national territory, which is made up of 1.798 localities (IPSE, 2018). Fourteen of these localities have energy contributions from renewable energy sources: eight have energy contributions from unconventional sources, seven have photovoltaic solar installations, and one works with biomass generation. Out of these 14 locations, only three lack diesel generation support, and the remaining 11 have this energy contribution (IPSE, 2019).

The operation of the electric power supply systems in these areas is supported by some economic funds that aim to boost the expansion of service provision. The existing funds are the Financial Support Fund for the Energization of Non-Interconnected Areas (FAZNI), the Non-Conventional Energy Fund and Efficient Energy Management (FENOGE), and the General Royalty System (SGR). These funds were implemented for the improvement of energy infrastructure, the proposal of new rural energy projects, etc. The funds have become a key point for the adequation of electric power supply facilities, resulting in improvements in the efficiency, quality, and continuity of service provision in these areas.

The Colombian ZNI has energy contributions amounting to $96 \%$ of diesel generation and $4 \%$ of other generation sources (IPSE, 2019, Flórez-Acosta, 2009). When diesel is established as the main source of generation, the supply costs increase due to fuel purchase and transportation costs for some localities, given that these are areas with difficult access, and, thus, the means of transportation of the fuel are the air or rivers. Furthermore, due to diesel-based generation, the carbon footprint of the Colombian energy supply systems has increased, as well as the pollution and contamination of ecosystems (González-Montoya et al., 2018, Garzón-Hidalgo \& Saavedra-Montes, 2017).

These areas are characterized by their great distance to the main urban centers; they are areas with difficult access, and many of them are in 26 national parks and environmentally protected areas. A considerable percentage of them supply electric power to 1.448 communities in tropical forests, deserts, snow-capped mountains, and more than 544 indigenous reservations (Gaona et al., 2015, López-García et al., 2018). Thereupon, these areas are located where most of the country's biodiversity is found, thus making it impossible to expand the transmission lines of the National Interconnected System (SIN) to these locations (Bustos-González et al., 2014).

Additionally, there are some challenges that hinder the provision of the service, such as low population density and low payment capacity. These populations are characterized by having a reduced coverage of the electricity service, and they have a low level of electric energy consumption and high service delivery costs, in addition to the lack of measurement by the generator and end users (IPSE, 2017). 
When examining the different difficulties of the ZNI, such as fuel transportation, the cost of generation, and the low variability of generation sources on site, together with the challenges presented by the population residing in these environmentally protected areas, the electric power service becomes noticeably limited and with reduced quality and reliability, as well as with continuity problems. A clear example of this problem is the provision of the service for the 14 locations that have energy contributions from non-conventional renewable energy sources (FNCER) since they have an average daily supply of 15 hours and 16 minutes, as shown in Table 2. Mitú, Vaupés has a 24-hour service, thus making this town the only one with energy contributions from renewable energy sources combined with diesel generation (IPSE, 2019).

Therefore, it is evident that the Colombian ZNI presents challenges in energy sustainability, since there is no balance between energy security, social equity, and environmental impact mitigation (Grisales, 2017).

\section{Sustainability challenges in the Colombian ZNI}

The Colombian ZNI is exposed to different challenges, not only in technical matters, but also in the social, economic, and environmental fields. These challenges must be addressed according to the level of urgency and their implications according to the time scale in which they are analyzed, as shown in Table 1.

These challenges show that the energy management carried out in the ZNI must be reconsidered; it must focus on finding energy solutions that address the different technical, environmental, economic, and social issues of these areas. It is necessary to work for a reliable and continuous supply of electricity with quality standards, which decreases the negative impacts suffered by the inhabitants of these localities and takes advantage of the different energy potentials of each community given the natural wealth of the Colombian ZNI (UPME, 2015).

By overcoming of these challenges through the operation of isolated microgrids, these areas have the potential to become a natural laboratory for Colombia, which allows analyzing the effect of the inclusion of variable generation resources, as well as identifying the aspects andmost relevant considerations that must be taken into account for the coordination of DERs (López-García et al., 2018).

\section{INTERNATIONAL EXPERIENCES}

In general, the energy solutions for remote rural regions base their operation on small diesel generators connected at the distribution level, which entails high generation costs and irreversible environmental damage (Rodríguez et al., 2017). Therefore, countries have focused on searching for

alternatives to improve service provision and reduce greenhouse gas emissions to the atmosphere resulting from the burning of fossil fuels (López-García et al., 2018). 
A Comprehensive Review of Sustainability in Isolated Colombian Microgrids Rodríguez-Zabala., A. López-García., D. Carvajal-Quintero., S.X. y Arango-Manrique., A

Table 1. Challenges related to technical, economic, social, and environmental sustainability in the short, medium, and long term for the operation and planning of the electricity supply in the Colombian ZNI

\begin{tabular}{|c|c|c|c|}
\hline \multirow{2}{*}{ Challenge } & \multicolumn{3}{|c|}{ Time horizon } \\
\hline & Short term & Medium term & Long term \\
\hline $\begin{array}{l}\text { Technical } \\
\text { Sustainability }\end{array}$ & $\begin{array}{l}\text { Blackouts during } \\
\text { peak hours due to the } \\
\text { high concentration of } \\
\text { residential, commercial, } \\
\text { and service constructions } \\
\text { without bioclimatic analysis. } \\
\text { Ignorance of the need } \\
\text { to make rational use } \\
\text { of energy. }\end{array}$ & $\begin{array}{l}\text { Increase of electrical losses } \\
\text { in distribution networks due } \\
\text { to massive and } \\
\text { uncoordinated growth in } \\
\text { demand and the installation } \\
\text { of appliances with reduced } \\
\text { efficiency, as well as } \\
\text { energy costs related to } \\
\text { the adaptation of habitat } \\
\text { space and lack of measurement } \\
\text { of electricity consumption } \\
\text { by the end user. }\end{array}$ & $\begin{array}{l}\text { The need to expand } \\
\text { conventional generation } \\
\text { capacity from fossil fuels. } \\
\text { The need for expansion and } \\
\text { modernization of } \\
\text { distribution networks. }\end{array}$ \\
\hline $\begin{array}{l}\text { Economic } \\
\text { sustainability }\end{array}$ & $\begin{array}{l}\text { High costs of } \\
\text { generation and fuel } \\
\text { transportation, as well } \\
\text { as low profitability of } \\
\text { the companies } \\
\text { providing the service. }\end{array}$ & $\begin{array}{l}\text { Increase in the value of } \\
\text { electricity. } \\
\text { Reduction of service } \\
\text { quality. }\end{array}$ & $\begin{array}{l}\text { Reduction of service } \\
\text { availability hours due to the } \\
\text { need to reduce operating } \\
\text { costs. } \\
\text { Need to increase government } \\
\text { subsidies. } \\
\text { Need to boost investment in } \\
\text { projects in order to expand } \\
\text { the provision of electric } \\
\text { power service. }\end{array}$ \\
\hline $\begin{array}{l}\text { Social } \\
\text { sustainability }\end{array}$ & $\begin{array}{l}\text { Resistance to } \\
\text { measurement and } \\
\text { control projects. }\end{array}$ & $\begin{array}{l}\text { Aversion to supply failures } \\
\text { that have an impact on the } \\
\text { already decreased quality } \\
\text { of life. }\end{array}$ & $\begin{array}{l}\text { Increase in the social gap and } \\
\text { reduction of social equity } \\
\text { due to a supply of electricity } \\
\text { with reduced quality and } \\
\text { high volatility. }\end{array}$ \\
\hline $\begin{array}{l}\text { Environmental } \\
\text { sustainability }\end{array}$ & $\begin{array}{l}\text { Ecosystem } \\
\text { intervention with } \\
\text { mass burning of fossil } \\
\text { fuels. }\end{array}$ & $\begin{array}{l}\text { Changes in ambient } \\
\text { temperature. } \\
\text { Increase in the emission of } \\
\text { greenhouse gases due to } \\
\text { fossil fuel generation. }\end{array}$ & $\begin{array}{l}\text { Permanent modifications to } \\
\text { protected ecosystems by fuel } \\
\text { spills, hydrocarbon-based } \\
\text { production, and the } \\
\text { construction of new } \\
\text { infrastructure. } \\
\text { Need to promote the use of } \\
\text { FNCER. }\end{array}$ \\
\hline
\end{tabular}

Source: Own elaboration based on the literature (Blasques \& Pinho, 2012,IPSE, 2019, SGI\&C -

FNCER, 2018).

Tecnura • p-ISSN: 0123-921X • e-ISSN: 2248-7638 • Volumen 25 Número $70 \bullet$ Octubre - Diciembre de $2021 \bullet$ pp. 126-145 
One of the alternatives proposed worldwide is energization by isolated microgrids because, given their technical characteristics, they allow improving the living conditions of end users and, above all, they benefit the local populations in remote areas of a given country, where it is difficult to provide the service either due to environmental, technical, topographic, or climatic conditions. Microgrids have the possibility of supplying uninterrupted electricity, improving reliability, reducing losses, providing greater security, and adopting distributed generation sources (Chowdhury et al., 2009, Adrián et al., 2016). These electrical systems are relatively new, which is why pilot projects are being developed in different educational institutions, and microgrids have been installed in different parts of the world to obtain an evaluation of these systems in order to gain knowledge and experience in the implementation of these technologies (Gaona et al., 2015). Below are some international pilot projects that have been successful in implementing isolated microgrids.

The microgrid project of the Kythnos island community, located in Greece, is $4 \mathrm{~km}$ away from the nearest medium voltage network, and it is capable of supplying electricity to 12 houses (Dafermos et al., 2015). This microgrid has become a pioneering project on issues related to the use of microgrids for energization in isolated areas of Europe. It consists of two photovoltaic plants with a rated capacity equal to 10 and $2 \mathrm{~kW}$, a battery bank of $53 \mathrm{kWh}$ with nominal capacity, and a diesel generator set of $5 \mathrm{kVA}$ (Rese, 2012). Moreover, a load disconnection occurs when the battery charge level is too low (López-García et al., 2018).

On the other hand, the village of Hartley Bay, located in British Columbia, Canada, is an isolated village of difficult access; its means of transportation are air and rivers, and it has a total population of 200 inhabitants ( $\mathrm{RCCbc}$, n.d.). The electric power service is provided through a microgrid with three diesel generators, which provides electricity to 20 commercial buildings and 62 residential units. Also, a demand response program has been implemented to use diesel generators as little as possible, thus optimizing diesel clearance (López-García, 2018).

In South America, there is the microgrid called Huatacondo, which is located in Chile and supplies electricity to approximately 30 families. It is made up of a $150 \mathrm{~kW}$ diesel generator, together with a $22 \mathrm{~kW}$ solar photovoltaic monitoring system, a $3 \mathrm{~kW}$ wind turbine, a $170 \mathrm{kWh}$ battery, and an energy management system (Berkeley Lab, 2020). In addition to this, it has a social SCADA that allows monitoring, operating, controlling, and supervising the electrical system (Núñez et al., 2013).

In February 2008, the island of Eigg, located in Scotland, began to generate its electricity through a microgrid that supplies energy 24 hours a day. The system allows service to 83 inhabitants who make up 38 homes and five commercial properties. The microgrid has a capacity comprising $119 \mathrm{~kW}$ of hydroelectric power, $24 \mathrm{~kW}$ of wind power, and approximately $54 \mathrm{~kW}$ of solar energy, together with a storage system and $160 \mathrm{~kW}$ of diesel generation as a backup. Thus, it has a total capacity approximately $357 \mathrm{~kW}$. Users have limited service access: in the case of residential users, they cannot exceed $5 \mathrm{~kW}$; and commercial users cannot exceed $10 \mathrm{~kW}$ each. Each resident has an energy monitoring system that helps users to not exceed the established load limits (Chmiel \& Bhattacharyya, 2015). 
The Hailuoto microgrid, located in Finland, is a pilot project that aims to demonstrate the island operation mode of microgrids in a medium voltage distribution system. Hailuoto has a population of 1.000 inhabitants and 600 holiday homes. The microgrid has a capacity of 0,5 MW of wind power and 1,5 MW of diesel generation (Laaksonen et al., 2014).

At the international level, projects related to microgrids have increased, as they represent a sustainable solution for rural electrification, given that they allow integrating renewable energy sources with diesel generation. Some experiences show that existing microgrids involve the community in the design, operation, and maintenance process, thus constituting an opportunity to raise awareness in the rational and efficient use of energy and ensuring the sustainability of the microgrid (Intergovernmental Panel on Climate Change, 2014).

In some African regions such as Kenya, Nigeria, and Tanzania, some microgrids to solve the rural electrification problem have been implemented. In this region, the solutions are hybrid microgrids with solar, wind, or hydraulic generation, supplemented with biomass or diesel generators (Plain et al., 2019). The connected users have smart metering, and the data gathered from measuring devices can parameterize the microgrid's performance in terms of quality. This information is used to create a conceptual framework to develop microgrids for rural electrification solutions (Li et al., 2020).

\section{Microgrids in Colombia}

Currently in Colombia, the country's energy production in isolated areas consists of approximately $93 \%$ of primary resources of fossil origin, approximately $4 \%$ of hydrogeneration, and $3 \%$ of biomass and other resources. For this reason, the Colombian government is in the process of creating and modifying some norms and laws that encourage the use of the FNCER on these regions by reducing the dependence on fossil fuels and diversifying the energy matrix. For the Colombian ZNI, these sources of generation represent sustainable environmental and social solutions over time which can complement the currently implemented conventional technologies, which constitutes an alternative to improve service delivery to the most vulnerable populations in Colombia (UPME, 2015).

The Colombian ZNI has general issues in the provision of the electric energy service, which are related to the coverage of the electric power service to the most remote populations, as well as to the little use of the primary energy resources in the different regions. The Colombian government, through the Institute for Planning and Promotion of Energy Solutions for Non-Interconnected Areas (IPSE), has installed hybrid generation projects in some isolated zones, seeking to provide a solution to the problem of electricity supply in rural areas. These different projects have been developed with the participation of conventional and unconventional generation (Gaona et al., 2015). Table 2 shows the general characteristics regarding the composition of the energy matrix, the number of users, and the average daily hours of service provision of some of the projects that have energy contributions from renewable energy sources located in the ZNI. 
However, the coordination and monitoring of these resources are still incipient, so it is necessary to carry out modernizations and updates of the distribution networks and the measurement and control systems, which allow these projects to become natural laboratories for the inclusion of DERs in Colombian distribution networks.

\section{Proposed solution for THE ENERgization OF THE COLOMBIAN NON-}

\section{INTERDONNECTED ZONES}

Considering the previously analyzed information regarding international experiences related to microgrid management and the Colombian challenges for the electrification of rural or isolated areas, some of the variables involved in the problem are analyzed, which allow identifying and describing the operation of the Colombian ZNI, integrating microgrids as a solution hypothesis for the electrification of these isolated areas. The employed methodology is System Dynamics (SD), which analyzes the cause-effect relationships between the different variables that interact in the system and allows a holistic analysis in which the response of the diverse actors is evaluated (Sterman, 2000). Figure 1 shows the variables that directly affect the model (endogenous), those that allow formulating the problem (exogenous), and those that provide an approach to the proposals (excluded), which interact in the cause-effect relationships model identified for the sustainable operation of microgrids with DG in the ZNI.

From the defined variables, the interaction between them and their impact on the problem solution is modeled. The model comprises three cycles that integrate the technical, environmental, and economic aspects that must be considered when implementing isolated microgrids as a proposal for the electrification of these areas (Figure 2). The proposed model for adopting microgrids in the Colombian ZNI will guarantee the supply of electricity to isolated regions of the country with continuity and quality indexes higher than those currently presented (López-García et al., 2018).

The cycles that make up the model are: a) the technical cycle, in which it is proposed to improve the efficiency, continuity, and supply quality indexes through the use of the region's energy potentials and the coordination of the DG immersed in the microgrid, thus allowing the provision of technical support services for real-time keeping of the technical variables of the system within acceptable limits (López-García, 2018,Manrique, 2017); b) the environmental cycle, where it is shown that, although all energy use has environmental effects in its design, construction, or operation, among the variety of small-scale generation technologies existing in the country, the fossil fuel-dependent generation units stand out for their environmental impact on the ecosystems in which they are immersed (Iberdrola, 2013); c) the economic cycle, which shows the possibility of reducing the service provision costs by reducing the dependence on diesel, which is related to high transport costs and in turn reduces power losses. With the coordination of the DGs present in the region, the energy potentials in the area would be used, considering that the cost of exploiting these primary energy resources is comparatively 
Table 2. General characteristics regarding the composition of the energy matrix, the number of users, and the average daily hours of service provision of some of the projects that have energy contributions from renewable energy sources located in the Colombian ZNI

\begin{tabular}{|c|c|c|c|c|c|c|c|c|c|c|}
\hline \multirow{2}{*}{$\begin{array}{c}\text { Locality } \\
\text { name - } \\
\text { Location }\end{array}$} & \multicolumn{3}{|c|}{$\begin{array}{c}\text { Conventional } \\
\text { generation capacity } \\
{[\mathrm{kW}]}\end{array}$} & \multicolumn{4}{|c|}{$\begin{array}{l}\text { Unconventional generation } \\
\text { capacity }[\mathrm{kW}]\end{array}$} & \multirow[t]{2}{*}{$\begin{array}{l}\text { Storage } \\
\text { systems }\end{array}$} & \multirow{2}{*}{$\begin{array}{c}\text { Daily } \\
\text { average } \\
\text { service } \\
\text { provision }\end{array}$} & \multirow{2}{*}{$\begin{array}{c}\text { Number } \\
\text { of } \\
\text { users }\end{array}$} \\
\hline & SHP & Diesel & $\begin{array}{c}\text { Share } \\
{[\%]}\end{array}$ & $\begin{array}{l}\text { Solar } \\
\text { PV }\end{array}$ & Biomass & $\begin{array}{l}\text { Wind } \\
\text { energy }\end{array}$ & $\begin{array}{c}\text { Share } \\
{[\%]}\end{array}$ & & & \\
\hline $\begin{array}{l}\text { Isla Fuerte - } \\
\text { Bolívar }\end{array}$ & 0 & 320 & $64,6 \%$ & 175 & 0 & 0 & $35,4 \%$ & - & 4,51 & 406 \\
\hline $\begin{array}{l}\text { Isla Múcura - } \\
\text { Bolívar }\end{array}$ & 0 & 116 & $79,5 \%$ & 30 & 0 & 0 & $20,5 \%$ & Yes & 14,56 & 43 \\
\hline $\begin{array}{c}\text { Santa Cruz } \\
\text { del Islote - } \\
\text { Bolívar }\end{array}$ & 0 & 116 & $63,0 \%$ & 68 & 0 & 0 & $37,0 \%$ & Yes & 13,41 & 127 \\
\hline $\begin{array}{l}\text { Guacamayas } \\
\text { - Caquetá }\end{array}$ & 150 & 0 & $100,0 \%$ & 0 & 0 & 0 & $0,0 \%$ & - & 18,8 & 205 \\
\hline $\begin{array}{c}\text { Santa } \\
\text { Bárbara - } \\
\text { Casanare }\end{array}$ & 0 & 23 & $53,5 \%$ & 0 & 20 & 0 & $46,5 \%$ & - & * & 17 \\
\hline $\begin{array}{c}\text { Comunidad } \\
\text { Indígena De } \\
\text { Pangui - } \\
\text { Chocó }\end{array}$ & 32 & 0 & $100,0 \%$ & 0 & 0 & 0 & $0,0 \%$ & - & 21,35 & 88 \\
\hline $\begin{array}{l}\text { Cúpica - } \\
\text { Chocó }\end{array}$ & 300 & 125 & $100,0 \%$ & 0 & 0 & 0 & $0,0 \%$ & - & 16,33 & 344 \\
\hline $\begin{array}{l}\text { Mutis - } \\
\text { Chocó }\end{array}$ & 1875 & 1800 & $100,0 \%$ & 0 & 0 & 0 & $0,0 \%$ & - & 23,44 & 166 \\
\hline $\begin{array}{c}\text { San } \\
\text { Francisco - } \\
\text { Chocó }\end{array}$ & 0 & 224 & $65,1 \%$ & 120 & 0 & 0 & $34,9 \%$ & Yes & & 266 \\
\hline $\begin{array}{l}\text { Titumate - } \\
\text { Chocó }\end{array}$ & 0 & 124 & $54,1 \%$ & 105 & 0 & 0 & $45,9 \%$ & - & 1,32 & 105 \\
\hline $\begin{array}{l}\text { Barranco } \\
\text { Minas - } \\
\text { Guainía }\end{array}$ & 0 & 401 & $87,2 \%$ & 58,88 & 0 & 0 & $12,8 \%$ & Yes & 8 & 352 \\
\hline $\begin{array}{l}\text { Nazareth - } \\
\text { La Guajira }\end{array}$ & 0 & 364 & $41,2 \%$ & 320 & 0 & 200 & $58,8 \%$ & Yes & 8,28 & 146 \\
\hline $\begin{array}{c}\text { Palmor } \\
\text { Ciénaga - } \\
\text { Magdalena }\end{array}$ & 373 & 0 & $100,0 \%$ & 0 & 0 & 0 & $0,0 \%$ & - & 23,13 & 436 \\
\hline $\begin{array}{l}\text { Mitú - } \\
\text { Vaupés }\end{array}$ & 2000 & 4512 & $100,0 \%$ & 0 & 0 & 0 & $0,0 \%$ & - & 24 & 2.293 \\
\hline
\end{tabular}

Source: Own elaboration based on the literature (Blasques \& Pinho, 2012,SGI\&C - FNCER, 2018). 


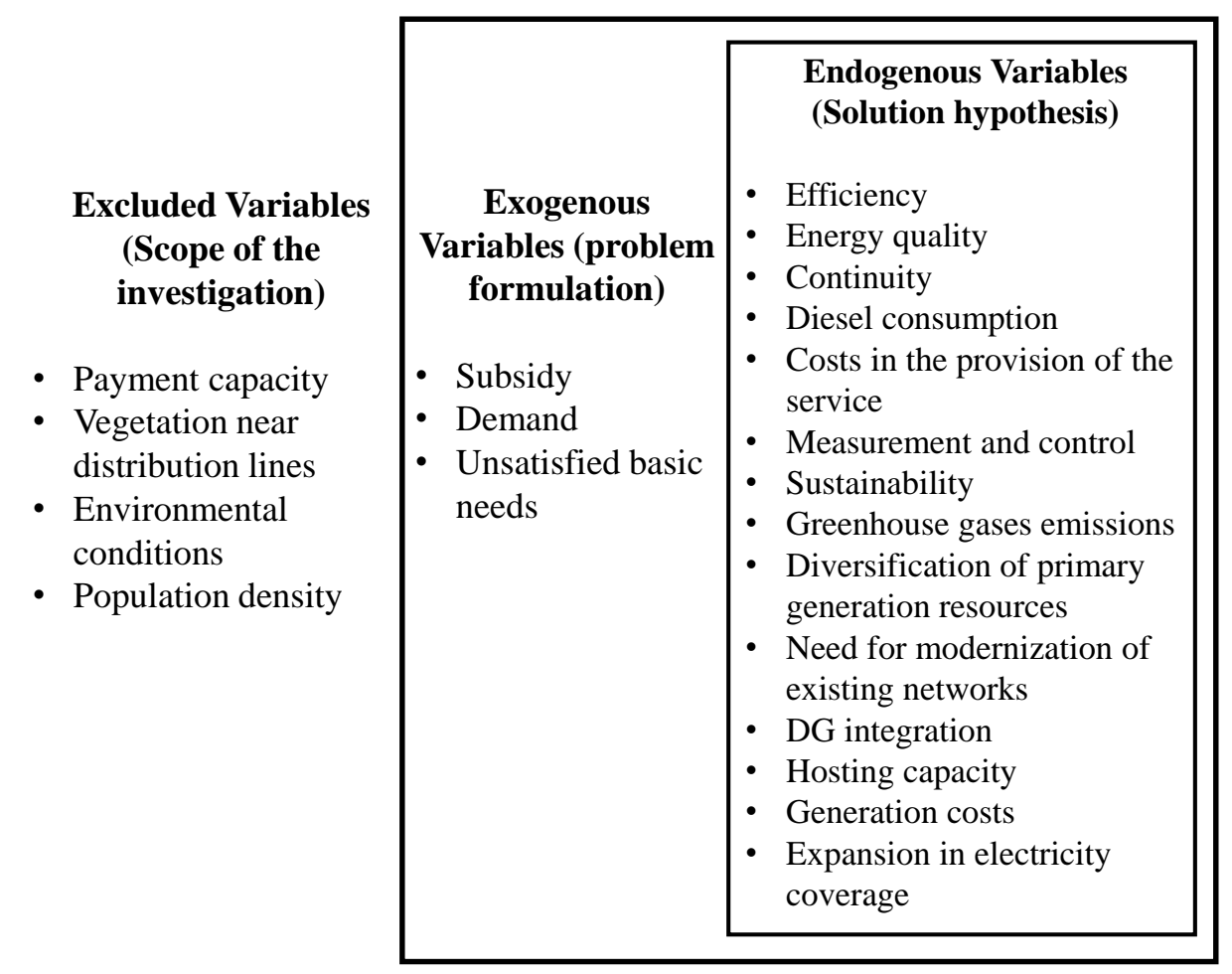

Figure 1. Defined variables of the proposed model

Source: Authors.

lower than the one incurred with the purchase of diesel (López-García, 2018, Manrique, 2017).

At the same time, the use of renewable generation sources contributes, when compared with current energy production, to have lower $\mathrm{CO}_{2}$ emissions and greater competitiveness in the market (Departamento Nacional de Planeación, World Bank Group, \& Korea Green Growth Partnership, 2017).

\section{Technical cycle}

The provision of electric power service in isolated areas depends partially on quality, continuity, and efficiency indicators to verify that the proposed solution is sustainable (Balcells et al., 2010). According to international experiences, the need to modernize existing networks by adopting relatively new technologies such as storage systems, demand response programs, and unconventional energy sources is evident (Chowdhury et al., 2009). Therefore, when trying to integrate non-conventional renewable generation sources in the operation of these microgrids, it is necessary to have measurement and control systems, due to the possible intermittency and variability of the primary energy resource used for generation. With the inclusion of these control technologies, it would be possible to coordinate the resources immersed in the microgrid (North American Electric Reliability Corporation, 2009). 


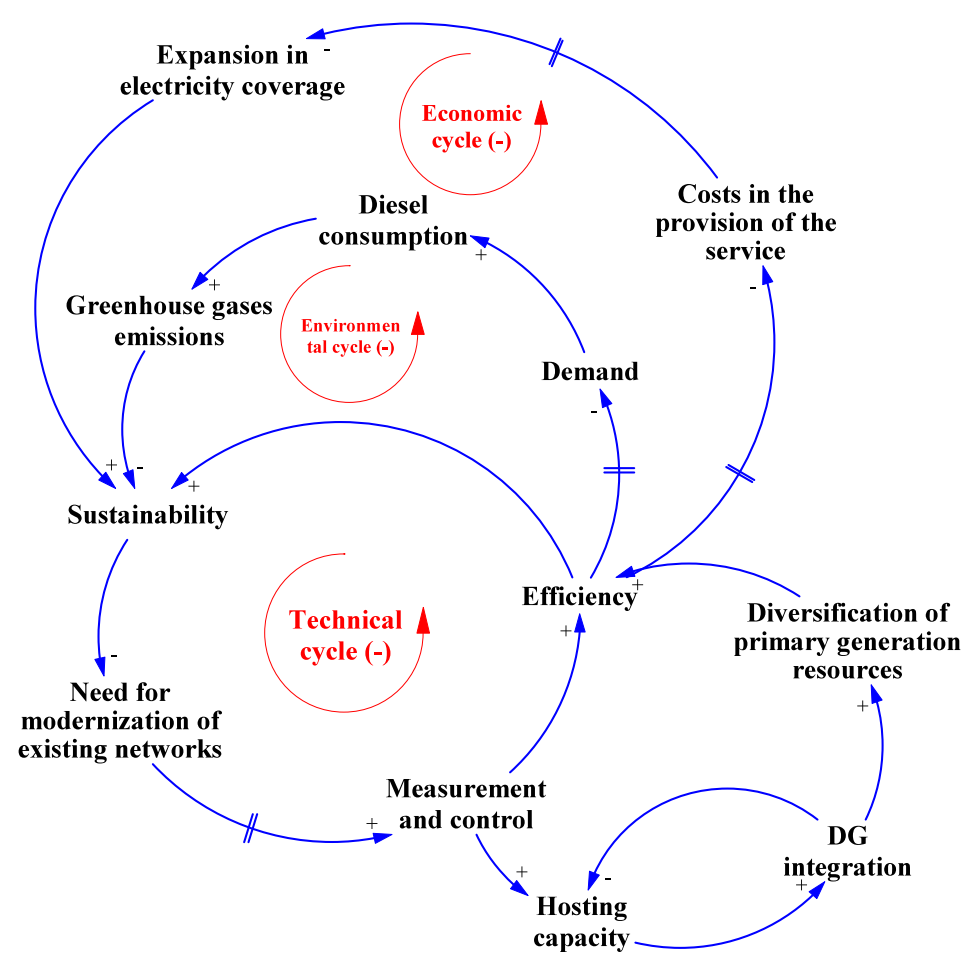

Figure 2. Proposed causal model

Source: Authors.

As there is greater sustainability in the operation of microgrids, the need for network modernization decreases, since energy security in the provision of the service is adequate, that is, it allows the service to be provided safely. If, on the contrary, the need to modernize networks grows, this leads to structural and operational changes in the system within a given time horizon (Grisales, 2017, BuenoLópez et al., 2020).

For its part, the hosting capacity establishes the appropriate limit for the adoption of DG in the network without affecting reliability and energy quality, thus becoming one of the main characteristics to be considered in the operation of isolated microgrids (Etherden \& Bollen, 2011). A higher hosting capacity leads to greater participation of DG. Of course, since this capacity is finite, there will be a point at which it will not be possible to integrate more resources, even with proper management (Bedoya-Bedoya, 2019). With an appropriate integration of these resources, it is possible to have greater flexibility in the operation of the networks, given the different forms of generation and possibilities for managing demand, thus reducing consumption and technical losses (Bedoya-Bedoya, 2019). 
Microgrids with DG inclusion have become an alternative to improve service delivery in isolated areas (López-García et al., 2018). Therefore, it is necessary to increase the hosting capacity of these sources without compromising the reliability and quality of the supply or exceeding the maximum penetration limit of each source, thus ensuring the operational performance of the system (Delgado et al., 2019, Valencia-López et al., 2017).

\section{Environmental cycle}

Demand growth is one aspect that affects the operation of distribution networks located throughout the territory (Morales-Ramírez \& Alvarado-Lagunas, 2014). In the case of the Colombian ZNI, this growth causes adverse environmental effects in the short, medium, and long term, which results from the strong dependence on diesel generation in these areas (Flórez-Acosta, 2009). Therefore, as the demand for fossil fuel burning increases, it also grows due to the need for energy supply and security (Camargo et al., 2013).

The progressive replacement of diesel generation is an alternative that allows reducing the negative impact of this type of generation on the environmentally protected ecosystems and areas in which these networks are usually located, and this is the result of the adoption of renewable energy sources and the gradual decrease of the dependency on generation based on fossil fuels (Camargo et al., 2013). Therefore, implementing these sources allows for environmental sustainability in the networks since it is possible to reduce the carbon footprint (Law 1715 of 2014, Giral-Ramírez, 2017).

\section{Economic cycle}

If the operation of an electrical system is efficient, the costs of providing the service are stable and may be affordable for end users (Flórez-Acosta, 2009). If, on the contrary, the system does not have efficiency and quality, the provision costs increase, affecting the final user. Given the social and economic characteristics of these regions, the costs of providing the service are too high to be fully covered by the end user (IPSE, 2017). This leads to a barrier on the expansion of the provision of the service, and it makes these systems unprofitable investments for companies in charge of generating, distributing, and commercializing electric energy, which leads to a reduction in the economic and social sustainability for the agents involved in the provision of energy.

The costs of providing services in these areas also increase as long as the participation of fossil fuel-based generation sources is predominant (González-Montoya et al., 2018). When analyzing the possibility of reducing diesel consumption, the subsidies used for the purchase of fuels could be redirected and used for the adaptation and modification of networks. In this way, it will be possible to take advantage of the energy potentials of each region and increase the electricity coverage of isolated areas in the Colombian territory (López-García et al., 2018). 


\section{CONCLUSIONS}

With the review of some projects that integrate microgrids to the electrification of rural or isolated areas around the world, it is observed that the operation of isolated microgrids in which the DERs are integrated becomes a sustainable solution for the energization of rural or isolated areas.

International experiences show that it is necessary to make investments in the modernization and control of the distribution network in order to guarantee the use of resources and rely on the electricity supply throughout the day. Additionally, it is observed that it is necessary to include the community in these projects for the adequate use of the potential resources of the regions, as well as for the operation to be sustainable over time.

The proposed solution, implemented according to the System Dynamics methodology, models and integrates the main variables involved in the operation of microgrids, showing the cause-andeffect relationships of all participants in order to analyze the possible implementation of policies that guarantee the sustainability of these solutions and potentiate the use of energy resources in each of the regions to contribute to the reduction of the carbon footprint and other environmental conditions resulting from diesel-based generation. Also, sustainability and continuity in the service improve people's living conditions and provide coverage for unsatisfied basic needs. In this sense, continuity promotes the implementation of productive projects, such as companies whose connection to the electricity grid boosts the household economy and encourages new ventures. Therefore, these projects increase the income of end users and provide economic development to the regions.

\section{ACKNOWLeDgments}

The authors wish to acknowledge the financial support of the Vice-Principalship for Research for the financing of this research through the approval of the project "Modeling and simulation of incentives for energy efficiency in Non-Interconnected Zones (ZNI)", with Hermes code 47501.

\section{REFERENCES}

[Adrián et al., 2016] Adrián, C., Flórez, C., Alberto, G., García, M., Felipe, A., \& Hernández, P. (2016). Impacto de la penetración de la energía solar fotovoltaica en sistemas de distribución: estudio bajo supuestos del contexto colombiano. Tecnura, 20(50), 85-95. https: / / doi .org/10.14483/ udistrital.jour.tecnura.2016.4.a06 \$See page 133

[Ahmad et al., 2016] Ahmad, S., Mat Tahar, R., Muhammad-Sukki, F., Munir, A. B., \& Abdul Rahim, R. (2016). Application of system dynamics approach in electricity sector modelling: A review. Renewable and Sustainable Energy Reviews, 56, 29-37. https: / / doi.org/10.1016/j.rser.2015. $11.034 \uparrow$ See page 129 
[Anderson \& Cardell, 2014] Anderson, C. L., \& Cardell, J. B. (2014). A Decision Framework for Optimal Pairing of Wind and Demand Response Resources. IEEE Systems Journal, 8(4), 1104-1111. https://doi.org/10.1109/JSYST.2014.2326898 \$See page

[Balcells et al., 2010] Balcells, J., Autonell, J., Barra, V., Brossa, J., Fornieles, F., Garcia, B., \& Ros, J. (2010). Eficiencia en el uso de la energía eléctrica. Marcombo - Circutor. $\uparrow$ See page 137

[Bedoya-Bedoya, 2019] Bedoya-Bedoya, D. E. (2019). Estudio del control de tensión en sistemas de distribución en Colombia con presencia de generación solar fotovoltaica [Master’s thesis]. $\uparrow$ See page 138

[Berkeley Lab, 2020] Berkeley Lab (2020). Microgrids at Berkeley Lab. https:// building-microgrid.lbl.gov/grid-planning-and-economics $\uparrow$ See page 133

[Blasques \& Pinho, 2012] Blasques, L. C. M., \& Pinho, J. T. (2012). Metering systems and demandside management models applied to hybrid renewable energy systems in micro-grid configuration. Energy Policy, 45, 721-729. https://doi.org/10.1016/j.enpol.2012.03.028 个See page 132,136

[Bordons et al., 2015] Bordons, C., García-Torres, F., \& Valverde, L. (2015). Gestión Óptima de la Energía en Microrredes con Generación Renovable. RIAI - Revista Iberoamericana de Automatica e Informatica Industrial, 12(2), 117-132. https://doi.org/10.1016/j.riai.2015.03.001 个See page 128

[Bueno-López et al., 2020] Bueno-López, M., González Cely, D. N., \& Muñoz Rincón, A. (2020). Análisis de expansión de una microrred en una zona no interconectada. Tecnura, 24(63), 40-56. https://doi.org/10.14483/22487638.15480个See page 138

[Bustos-González et al., 2014] Bustos-González, J. F., Sepúlveda, A. L., \& Triviño Aponte, K. (2014). Zonas no interconectadas eléctricamente en colombia: problemas y perspectiva. Econografos Escuela de Economía, 65. http://www.fce.unal.edu.co/publicaciones/images/ documentos-econografos-economia-65.pdf $\uparrow$ See page 130

[Camargo et al., 2013] Camargo, L. A., Arboleda, M. N., \& Cardona, E. (2013). Producción de energía limpia en Colombia, la base para un crecimiento sostenible. https: / /www.xm.com.co/Bolet inXM/ Documents/MDLColombia_Feb2013.pdf 个See page 139

[Cappers et al., 2011] Cappers, P., Nills, A. D., Goldman, C. D., Wiser, R. H., \& Eto, J. E. (2011). Mass market demand response and variable generation integration issues: A scoping study. October. Berkeley Lab. https://doi.org/10.2172/1051046 个See page

[Cappers et al., 2012] Cappers, P., Mills, A., Goldman, C., Wiser, R., \& Eto, J. H. (2012). An assessment of the role mass market demand response could play in contributing to the management of 
variable generation integration issues. Energy Policy, 48, 420-429. https://doi .org/10.1016/ j.enpol.2012.05.040 个See page

[Chmiel \& Bhattacharyya, 2015] Chmiel, Z., \& Bhattacharyya, S. C. (2015). Analysis of off-grid electricity system at Isle of Eigg (Scotland): Lessons for developing countries. Renewable Energy, 81, 578-588. https://doi.org/10.1016/J.RENENE.2015.03.061 个See page 133

[Chowdhury et al., 2009] Chowdhury, S., Chowdhury, S. P., \& Crossley, P. (2009). Microgrids and active distribution networks. In Microgrids and Active Distribution Networks. IET. https : / / do i . org / 10.1049 /pbrn006e $\uparrow$ See page 128, 133, 137

[Dafermos et al., 2015] Dafermos, G., Kotsampopoulos, P., Latoufis, K., Margaris, I. D., Rivela, B., Washima, F. P., Ariza-Montobbio, P., \& López, J. (2015). Energía: conocimientos libres, energía distribuida y empoderamiento social para un cambio de matriz energética. Buen Conocer - FLOK Society. $\uparrow$ See page 133

[Delgado et al., 2019] Delgado, A. J. S., Belman, B. L., \& Rodríguez-Villalón, O. (2019). Factibilidad técnica y económica de sistemas eléctricos operando bajo el esquema de red inteligente. Jóvenes en la ciencia, 5(1), 3082. https://www.jovenesenlaciencia.ugto.mx/index.php/ jovenesenlaciencia/article/view/3082/2544 个See page 139

[Departamento Nacional de Planeación, World Bank Group, \& Korea Green Growth Partnership, 2017] Departamento Nacional de Planeación, World Bank Group, \& Korea Green Growth Partnership (2017). Energy Supply Situation in Colombia. DNP. $\uparrow$ See page 137

[Etherden \& Bollen, 2011] Etherden, N., \& Bollen, M. H. J. (2011). Increasing the hosting capacity of distribution networks by curtailment of renewable energy resources [Conference presentation]. 2011 IEEE Trondheim PowerTech, Trondheim, Norway. https://doi.org/10.1109/PTC.2011. $6019292 \uparrow$ See page 138

[Flórez-Acosta, 2009] Flórez-Acosta, J. H., Tobón-Orozco, D., \& Castillo-Quintero, G. A. (2009). ¿Ha sido efectiva la promoción de soluciones energéticas en las zonas no interconectadas (ZNI) en Colombia?: Un análisis de la estructura institucional. Cuadernos de Administración, 22(38), 219-245. http://www.scielo.org.co/pdf/cadm/v22n38/v22n38a11.pdf $\uparrow$ See page 130, 139

[Gaona et al., 2015] Gaona, E. E., Trujillo, C. L., \& Guacaneme, J. A. (2015). Rural microgrids and its potential application in Colombia. Renewable and Sustainable Energy Reviews, 51, 125-137. https: //doi.org/10.1016/j.rser.2015.04.176 个See page 128,130,133, 134

[Garzón-Hidalgo \& Saavedra-Montes, 2017] Garzón-Hidalgo, J. D., \& Saavedra-Montes, A. J. (2017). A design methodology of microgrids for non-interconnected zones of Colombia. TecnoLógicas, 20(39),39-53. https://doi.org/10.22430/22565337.687 个See page 130 
[Giral-Ramírez, 2017] Giral-Ramírez, W. M., Celedón-Flórez, H. J., Galvis-Restrepo, E., \& Zona-Ortiz, A. T. (2017). Redes inteligentes en el sistema eléctrico colombiano: Revisión de tema. Tecnura, 21(53), 119-137. https: / / doi.org/10.14483/22487638.12396 See page 139

[Gómez et al., 2017] Gómez, C. R., Arango-Aramburo, S., \& Larsen, E. R. (2017). Construction of a Chilean energy matrix portraying energy source substitution: A system dynamics approach. Journal of Cleaner Production, 162, 903-913. https://doi.org/10.1016/j.jclepro.2017.06. $111 \uparrow$ See page 129

[González-Montoya et al., 2018] González-Montoya, D., Ramos-Paja, C. A., Potosí-Guerrero, B. A., Henao-Bravo, E. E., \& Saavedra-Montes, A. J. (2018). Análisis de factibilidad técnico-económico de microrredes que integran celdas de combustible en zonas no interconectadas de Colombia. TecnoLógicas, 21(43), 71-89. https: / / doi .org/10.22430/22565337.1057 个See page 130, 139

[Grisales, 2017] Grisales, S. (2017). Análisis de la viabilidad técnico - económica de la inclusión de energía renovable en una de las principales localidades de las ZNI [Master's thesis, Universidad Nacional de Colombia]. https://repositorio.unal.edu.co/handle/unal/60190 $\uparrow$ See page 131, 138

[Iberdrola, 2013] Iberdrola. (2013). Efectos ambientales de la producción y distribución de energía eléctrica: acciones para su control y corrección. Iberdrola. $\uparrow$ See page 135

[IPSE, 2017] Instituto De Planificación Y Promoción De Soluciones Energéticas Para Las Zonas No Interconectadas (IPSE) (2017). Informe Rendición Social De Cuentas 2016-2017. IPSE. $\uparrow$ See page 130, 139

[IPSE, 2018] Instituto de Planificación y Promoción de Soluciones Energéticas para las Zonas No Interconectadas (IPSE) (2018). Audiencia Pública de Rendición de Cuentas Vigencia 2017 - 2018. IPSE. $\uparrow$ See page 130

[IPSE, 2019] Instituto de Planificación y Promoción de Soluciones Energéticas para las Zonas No Interconectadas (IPSE) (2019). Informe de telemetría-agosto de 2019. IPSE. $\uparrow$ See page 130, 131, 132

[Intergovernmental Panel on Climate Change, 2014] Intergovernmental Panel on Climate Change. (2014). Climate Change 2013 - The Physical Science Basis. Cambridge University Press. https: //doi.org/10.1017/CB09781107415324.004 个See page 134

[Laaksonen et al., 2014] Laaksonen, H., Ishchenko, D., \& Oudalov, A. (2014). Adaptive protection and microgrid control design for Hailuoto Island. IEEE Transactions on Smart Grid, 5(3), 1486-1493. https://doi.org/10.1109/TSG.2013.2287672 个See page 134

[Law 143 of 1994] Law 143 of 1994, Por la cual se establece el régimen para la generación, interconexión, transmisión, distribución y comercialización de electricidad en el territorio nacional, se conceden unas autorizaciones y se dictan otras disposiciones en materia energética. July 
11, 1994. D.O. No.41.434. https: / /www.minenergia.gov.co/documents/10180/667537/ Ley_143_1994.pdf $\uparrow$ See page 130

[Law 1715 of 2014] Law 1715 of 2014. Por medio de la cual se regula la integración de las energías renovables al sistema energético nacional. May 13, 2014. D.O. 49.150. http://www. secretariasenado.gov.co/senado/basedoc/ley_1715_2014.html $\uparrow$ See page 139

[Li et al., 2020] Li, X., Booth, S., Esterly, S., Baring-Gould, I., Clowes, J., Weston, P., Shukla, P., Thacker, J., \& Jacquiau-Chamski, A. (2020). A product of the usaid-nrel partnership performance monitoring of african micro-grids: good practices and operational data energy 4 impact (January). USAID-NREL. https: / /www.nrel.gov/docs/fy20osti/71767.pdf. https: // doi.org/10.2172/1051046. 个See page 134

[Liévano Martínez \& Londoño, 2012] Liévano Martínez, F., \& Londoño, J. E. (2012). El pensamiento sistémico como herramienta metodológica para la resolución de problemas. Soluciones de Postgrado EIA, 8, 43-65. https://revistas.eia.edu.co/index.php/SDP/article/view/354 $\uparrow$ See page 129

[López-García et al., 2018] López-García D., Arango-Manrique A., C.-Q. S. X. (2018). The Impact of Residential Demand Response in the Active Power Balance of an Isolated Microgrid: A Case of Study. In J. Figueroa-García, E. López-Santana, J. Rodriguez-Molano (Eds.) Applied Computer Sciences in Engineering. WEA 2018. Communications in Computer and Information Science (vol. 915, pp. 535547). Springer. http://dx.doi.org/10.1007/978-3-030-00350-0_44 个See page 128, 130, $131,133,135,139$

[López-García, 2018] López-García, D., Arango-Manrique, A., \& Carvajal-Quintero, S. X. (2018). Integration of distributed energy resources in isolated microgrids: the Colombian paradigm. TecnoLógicas, 21(42), 13-30. https: / / doi .org/10.22430/22565337.774 个See page

[López-García, 2018] López-García, D. (2018). Caracterización de un esquema remunerativo para la participación de la demanda en la prestación del servicio complementario de control de frecuencia en el mercado eléctrico colombiano [Master's thesis, Universidad Nacional de Colombia]. https:// repositorio.unal.edu.co/handle/unal/ 76690 个See page 129, 133, 135, 137

[Manrique, 2017] Manrique, A. A. (2017). Evaluación Técnica y de Mercado de la Operación de una Microrred en Modo Aislado dentro de un Sistema Eléctrico de Potencia con Ambiente Desregulado [Doctoral thesis, Universidad Nacional de Colombia]. https: / / repositorio . unal . edu .co/handle/ unal/ $60939 \uparrow$ See page 135, 137

[Morales-Ramírez \& Alvarado-Lagunas, 2014] Morales-Ramírez, D., \& Alvarado-Lagunas, E. (2014). Análisis del consumo de energía eléctrica domiciliaria en Tampico, Tamaulipas. CienciaUAT, 8(2), 62-67. http://doi.org/10.29059/cienciauat.v8i2.290 个See page 139 
[North American Electric Reliability Corporation, 2009] North American Electric Reliability Corporation (2009). Accommodating High Levels of Variable Generation. NERC. $\uparrow$ See page 137

[Núñez et al., 2013] Núñez, O., Ortiz-Villalba, D., \& Palma-Behnke, R. (2013). Microrredes en la red eléctrica del futuro - caso Huatacondo. Ciencia y Tecnología: Revista de La Universidad de Costa Rica, 29(2), 1-16. https://revistas.ucr.ac.cr/index.php/cienciaytecnologia/ article/view/15214 $\uparrow$ See page 133

[Plain et al., 2019] Plain, N., Hingray, B., \& Mathy, S. (2019). Accounting for low solar resource days to size $100 \%$ solar microgrids power systems in Africa. Renewable Energy, 131, 448-458. https: //doi.org/10.1016/J.RENENE.2018.07.036个See page 134

[Rese, 2012] Rese, L. (2012). Modelagem, análise de estabilidade e controle de microrredes de energia elétrica [Master's thesis, Universidade Federal de Santa Catarina]. $\uparrow$ See page 133

[Rodríguez et al., 2017] Rodríguez, R., Osma, G., \& Ordóñez, G. (2017). Retos de la planificación energética de micro-redes en regiones rurales remotas con cargas dispersas Energy planning challenges of microgrid in remote rural regions with scattered loads. IX Simposio Internacional de La Calidad de La Energía Eléctrica - SICEL 2017. $\uparrow$ See page 131

[RCCbc, n.d.] Rural Coordination Centre of BC (RCCbc) (n.d.). Hartley Bay. https : / / rccbc.ca/ hartley-bay/ $\uparrow$ See page 133

[SGI\&C - FNCER, 2018] Sistema de Gestión de Información y Conocimiento en Fuentes No Convencionales deEnergía Renovable en Colombia (SGI\&C - FNCER). (2018). Sistemas Fotovoltaicos aislados en el municipio de Paratebueno - Cundinamarca. SGI\&C. $\uparrow$ See page 132, 136

[Sterman, 2000] Sterman, J. (2000). Business Dynamics: Systems Thinking and Modeling for a Complex World. McGraw-Hill Education $\uparrow$ See page 135

[UPME, 2015] Unidad de Planeación Minero Energética (UPME) (2015). Integración de las energías renovables no convencionales en Colombia. Ministerio de Minas y Energía. $\uparrow$ See page 131, 134

[Valencia-López et al., 2017] Valencia-López, D., Carvajal Quintero, S., \& Pineda-Agudelo, J. (2017). Design of demand management programs for the efficient use of electricity by industrial users. Ingeniería y Competitividad, 19(1),207-218. https://doi.org/10.25100/iyc.v19i1.2144 个See page 139

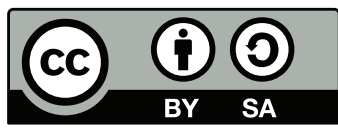

